\title{
Simultaneous Multielement Determination of Al, As, Cd, Cr, Cu, Fe, Hg, Mn, Ni, Pb, Sn, and Zn in Bulgur Wheat by ICP-OES
}

\author{
Sait Erdogan ${ }^{a}$, Isil Aydin ${ }^{b}, *$, M. Zahir Duz ${ }^{a}$, Firat Aydin ${ }^{a}$, K. Serdar Çelik ${ }^{c}$, Osman Akba ${ }^{a}$, Candan Hamamci ${ }^{a}$ \\ a Dicle University, Science Faculty, Chemistry Department, Diyarbakir, Turkey \\ b Dicle University, Pharmacy Faculty, Analytical Chemistry Department, Diyarbakır, Turkey \\ c Batman University, Science and Art Faculty, Chemistry Department, Batman, Turkey
}

\section{INTRODUCTION}

Minerals are fundamentally inorganic compounds and essential to life (1). Plant foods contain almost all of the minerals essential for human nutrition (2). Humans require a number of minerals known to play a key role in maintaining health (3). For the living organisms, food is the basic source of necessary elements. The levels of toxic and essential metals must be analyzed routinely (4). Like water, carbohydrates, proteins, fats, vitamins, and the enzymes required to digest them, minerals are also essential to life. The trace elements manganese (Mn), cobalt (Co), copper $(\mathrm{Cu})$, chromium $(\mathrm{Cr})$, iron $(\mathrm{Fe})$, nickel (Ni), tin ( $\mathrm{Sn})$, and zinc ( $\mathrm{Zn})$ are essential micro-nutrients for organisms. But if taken in excess, they can be toxic. However, some elements like arsenic (As), cadmium $(\mathrm{Cd})$, lead $(\mathrm{Pb})$, and mercury $(\mathrm{Hg})$ are non-essential metals and are toxic even at trace levels. Metals such as cadmium (Cd), aluminum (Al), and lead are found throughout the environment and are present virtually in all foods at extremely low levels (5-6).

Wheat, maize (corn), and rice are the most commonly grown cereals and the most widely used. These crops dominate world agricultural production with a combined annual yield of over 2000 million tonnes. Wheat (Triticum spp.), a cereal grain originally from Anatolia and now cultivated worldwide, is a type of grass best known for its

\section{ABSTRACT}

Bulgur is one of the oldest cereal-based foods. This study explains the simultaneous determination by the proposed method for toxic elements such as $\mathrm{Al}, \mathrm{As}, \mathrm{Cd}, \mathrm{Cr}, \mathrm{Cu}, \mathrm{Fe}, \mathrm{Hg}, \mathrm{Mn}$, $\mathrm{Ni}, \mathrm{Pb}, \mathrm{Sn}$, and $\mathrm{Zn}$ in bulgur by ICP-OES following digestion in a closed-vessel microwave system. The ICP-OES method is used because it is precise, rapid, simple, and accurate for the determination of 12 metals. The technique can be considered useful for the routine analysis of multi-elements in cereals as well as for quality control purposes. The obtained results in the bulgur samples (mean in $\mathrm{mg} \mathrm{kg}^{-1}$ ) were: Al 0.81, Cr 0.19, Cu 3.80, Fe 26.75, Mn 13.60, Ni 0.25, Pb 0.23 , Sn 0.17 , and $\mathrm{Zn} \mathrm{14.30.} \mathrm{The}$ concentrations of As, $\mathrm{Cd}$, and $\mathrm{Hg}$ were below the detection limits. A certified reference material was used to verify the accuracy of the studied method. The results were in good agreement with the certified values. The toxic metal concentrations are low and the obtained values are suitable for daily intake. The macro and micro nutrient ranges in bulgar wheat did not exceed the dietary reference intake (DRI). The bulgur produced in Turkey has very low levels of toxic metals, is safe for human consumption, and is a highly nutritional and healthy food source. Bulgur wheat is, therefore, safe for public consumption. grain. The wheat grain contains three groups of major constituents, proteins, starch, and cell wall polysaccharides, which together account for about $90 \%$ of the dry weight, and minor constituents that include phenolics, minerals, lipids, vitamins, and terpenoids (7). Its chemical composition depends on many factors, such as climate and cultivation of soil, so that the quality and commercial value are rather different based on geographical origin $(8,9)$. Bulgur is a very famous industrially processed ancient wheat product and is especially popular in Turkey and other eastern Mediterranean, Middle Eastern, and eastern European countries $(10,11)$. It is a whole grain product, which is generally produced from Triticum durum requiring cleaning, cooking, drying, tempering, dehulling, grinding, and classification operations (12). In Turkey, one million tons of bulgur is processed in about 500 factories and about $20 \%$ of bulgur production is exported (13). Bulgur is considered a "health food" in Europe and the USA and its consumption has been increasing (14). It can be categorized either as a semi-readyto-eat food or a ready-to-eat food (15). For bulgur production, cleaned and washed wheat grains are boiled for complete starch gelatinization. Then, they are dried to about $12 \%$ of moisture content. Bulgur is also important as a dietary fiber source, having $18.3 \mathrm{~g}$ dietary fiber per $100 \mathrm{~g}$. Its dietary fiber content is $6.8,4.3,3.5,2.3,1.8,1.3$, and 1.1 times higher than wheat flour, pasta, rice, wheat bread, oat meal, soybean, and barley, respectively (13). 
The consumption of bulgur is also important with regard to its economical and nutritional properties. In Turkey, the use of bulgur is approximately 2.5 and 2.0 times higher than that of pasta and rice, respectively. The average annual consumption of bulgur is about $12 \mathrm{~kg} /$ person in Turkey (13-15). It is an excellent food source due to its low cost, ease of preparation, long shelf life, and high nutritional value, which resists mould contamination and attack by mites and insects. It is more stable than wheat due to limited respiration, enzymatic and microbial activities during cooking in hot and humid environmental conditions $(10,14,16)$. Both bread wheat and durum wheat are used in bulgur preparation, though amber-colored durum wheat is preferred, but sometimes corn, oats, rye, barley, and soybean are also used (17).

Bulgur is also stored for military and human nutrition purposes in some countries because of its resistance to absorption of radiation, prevents cancer, and is consumable alone in diets. It is one of the important wheat products in the USA, and is one of the items on the special list of food rations to be stored in nuclear fallout shelters (18). Bulgur has the advantage of cooking more rapidly than whole or cracked wheat (19). Because, it is a whole grain food and popular in the health food sector, its hearty flavor lends itself to be included frequently in vegetarian meals (1013).

A healthy and balanced diet is essential for a good quality of life. In a typical diet problem, a cost function is minimized while satisfying the nutritional requirements (20). Based on low current intake, reported association with lower chronic disease risk, risk indicator and overweight, and higher overall diet quality, the 2010 Dietary Guidelines for Americans recommended an increased intake of whole grain (WG) and total dietary fiber (21). Drying, and indeed other thermal and even non-thermal processing, leads to a number of changes of wheat. These changes include physical, chemical, and/or biochemical changes (22).

The distinction of cereal and bulgur samples from different origins has been successfully carried out by measuring chemicals (e.g., lipids, proteins, minerals, stable isotopes) using various analytical techniques such as gas chromatography (GC), the Kjeldahl method, inductively coupled plasma mass spectrometry (ICP-MS), optical emission spectrometry (ICP-OES), and gas isotope instrumentation (23-28).

The proposed ICP-OES technique, which has been validated and developed for wheat bulgur samples, demonstrated to be rapid, simple, precise, and accurate for the simultaneous determination of 12 essential and/or toxic elements. These studies provide valuable information on the mineral charac-

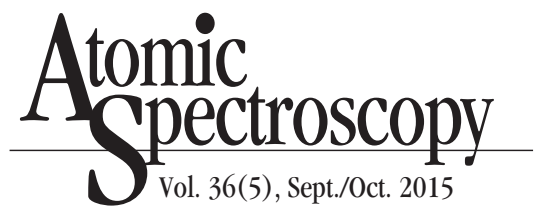

teristics of bulgur from SE Anatola, Turkey. This technique is a valuable and convenient method for the routine analysis of metals in foods and for quality control purposes.

\section{EXPERIMENTAL}

\section{Instrumentation}

An Optima ${ }^{\mathrm{TM}} 2100$ DV (dual view) inductively coupled plasma optical emission spectrometer (PerkinElmer, Inc., Shelton, CT, USA) was used for the determination of $\mathrm{Al}, \mathrm{As}, \mathrm{Cd}, \mathrm{Cr} \mathrm{Cu}, \mathrm{Fe}, \mathrm{Hg}, \mathrm{Ni}$, $\mathrm{Pb}, \mathrm{Sn}$, and $\mathrm{Zn}$ in bulgur wheat in diluted solutions. The instrumental operating parameters are listed in Table I. All of the procedures from sampling to analysis were also applied to blanks in order to evaluate any metal contamination during the analytical procedure. A blank was simultaneously prepared and all procedures were applied before measurements. Selection of the instrumental parameters and the optical wavelengths was based on obtaining good sensitivity, reason-

TABLE I

Instrumental Operating Conditions Using Optima ${ }^{\mathrm{TM}} 2100$ DV ICP-OES

\begin{tabular}{ll}
\hline Parameters & \\
\hline RF power & $1450 \mathrm{~W}$ \\
Plasma gas flow rate & $15 \mathrm{~L} \mathrm{~min}^{-1}$ \\
Auxiliary gas flow rate & $0.2 \mathrm{~L} \mathrm{~min}^{-1}$ \\
Nebulizer gas flow rate & $0.8 \mathrm{~L} \mathrm{~min}^{-1}$ \\
Sample flow rate & $1.5 \mathrm{~L} \mathrm{~min}{ }^{-1}$ \\
Viewing mode & Axial \\
Read & Peak area \\
Source equilibration time & $15 \mathrm{~s}$ \\
Read delay & $50 \mathrm{~s}$ \\
Replicates & 3 \\
Background correction & 2 -point (manual point correction) \\
Spray chamber & Scott-type spray chamber \\
Nebulizer & Cross-flow GemTip \\
& (HF resistant) \\
Detector & CCD \\
Purge gas & Nitrogen \\
Shear gas & Air \\
Gas & Argon \\
\hline
\end{tabular}


able detection limits, and eliminating interferences (29-30). All samples were digested and analyzed in triplicate. The analytical wavelenghths and average detection limits calculated for all measurements used are listed in Table II.

\section{Samples and Reagents}

A total of 30 bulgur samples was collected from southeastern Anatolia in 2012, which is one of the major wheat and bulgur producing regions in Turkey. Studies were carried out using different bulgur samples obtained at local markets and produced in Diyarbakir. All samples were commercially available. In order to preserve the original quality of the bulgur, the samples were stored at ambient temperature in sealed plastic bags prior to any conditioning.

Distilled water was further purified with a Milli-Q ${ }^{\circledR}$ system (Millipore Corporation, USA) and used throughout the experiments. Hydrogen peroxide $\left(\mathrm{H}_{2} \mathrm{O}_{2}, 30 \%\right)$ and nitric acid $\left(\mathrm{HNO}_{3}, 65 \%\right)$ used for the digestion were of analytical grade (E. Merck, Darmstadt, Germany).

TABLE II

Analytical Wavelengths $(\lambda)$, Detection Limits (LOD), Determination Limits (LOQ), Minimum, Maximum and Mean Concentration and Relative Standard Deviation (RSD) of the Chemical Elements in Bulgur Samples from Diyarbakir, Turkey

\begin{tabular}{cccccccc}
\hline Element & $\begin{array}{c}\lambda \\
(\mathrm{nm})\end{array}$ & $\begin{array}{c}\text { LOD } \\
(\mu \mathrm{g} \mathrm{kg}\end{array}$ & $\begin{array}{c}\text { LOQ } \\
\left(\mu \mathrm{kg}^{-1}\right)\end{array}$ & $\begin{array}{c}\text { Minimum } \\
\left(\mathrm{mg} \mathrm{kg}^{-1}\right)\end{array}$ & $\begin{array}{c}\text { Maximum } \\
\left(\mathrm{mg} \mathrm{kg}^{-1}\right)\end{array}$ & $\begin{array}{c}\text { Mean } \\
\left(\mathrm{mg} \mathrm{kg}^{-1}\right)\end{array}$ & $\begin{array}{c}\text { RSD } \\
(\%)\end{array}$ \\
\hline $\mathrm{Al}$ & 396.153 & 5.76 & 19.18 & 0.68 & 0.94 & 0.81 & 0.08 \\
$\mathrm{As}$ & 193.696 & 7.34 & 24.44 & $\mathrm{~N} . \mathrm{D}$ & $\mathrm{N} . \mathrm{D}$ & $\mathrm{N} . \mathrm{D}$ & $\mathrm{N} . \mathrm{D}$ \\
$\mathrm{Cd}$ & 228.802 & 6.48 & 21.58 & $\mathrm{~N} . \mathrm{D}$ & $\mathrm{N} . \mathrm{D}$ & $\mathrm{N} . \mathrm{D}$ & $\mathrm{N} . \mathrm{D}$ \\
$\mathrm{Cr}$ & 267.716 & 3.25 & 10.82 & 0.16 & 0.21 & 0.19 & 0.05 \\
$\mathrm{Cu}$ & 327.393 & 4.12 & 13.72 & 3.35 & 4.25 & 3.80 & 0.42 \\
$\mathrm{Fe}$ & 238.204 & 5.48 & 18.24 & 19.63 & 33.88 & 26.75 & 1.34 \\
$\mathrm{Hg}$ & 253.652 & 1.54 & 5.12 & $\mathrm{~N} . \mathrm{D}$ & $\mathrm{N} . \mathrm{D}$ & $\mathrm{N} . \mathrm{D}$ & $\mathrm{N} . \mathrm{D}$ \\
$\mathrm{Mn}$ & 257.610 & 6.97 & 23.21 & 9.24 & 17.96 & 13.60 & 0.96 \\
$\mathrm{Ni}$ & 231.634 & 5.49 & 18.28 & 0.14 & 0.37 & 0.25 & 0.04 \\
$\mathrm{~Pb}$ & 220.353 & 6.13 & 20.41 & 0.22 & 0.24 & 0.23 & 0.05 \\
$\mathrm{Sn}$ & 189.927 & 5.36 & 17.84 & 0.11 & 0.23 & 0.17 & 0.02 \\
$\mathrm{Zn}$ & 206.200 & 9.63 & 32.07 & 9.24 & 19.36 & 14.30 & 0.89 \\
\hline
\end{tabular}

for each metal were determined as follows: 10 independent analyses of a blank solution spiked with the metal at a level of lower concentration of the analytical curve were performed. The LOD and LOQ were calculated from the standard deviation $(\sigma)$ of these determinations $(\mathrm{LOD}=3 \times \sigma$ and LOQ $=$ $10 \times \sigma)(31)$. The analytical wavelengths, average detection limits calculated for all measurements, and the minimum, maximum, and average concentration of the elements in the bulgur samples are listed in Table II.

\section{Accuracy and Precision of the Method}

Certified standard reference material CRM 1573a Tomato Leaves (National Institute of Standards and Technology, NIST, Gaithersburg, MD, USA) was used to assess the accuracy and precision of the method. The accuracy of the entire proposed method was confirmed by standard reference material analysis. As can be seen in Table IV, the method was validated through the analysis of CRM NIST 1573a with good recoveries.

TABLE III

Temperature Program of the Microwave Digestion System for Bulgur Samples

\begin{tabular}{|c|c|c|c|}
\hline \multicolumn{4}{|l|}{ Step 1} \\
\hline $\mathrm{T}^{\circ} \mathrm{C}$ & 120 & 150 & 180 \\
\hline $\mathrm{Ta}(\min )^{\mathrm{a}}$ & 5 & 5 & 3 \\
\hline Time (min) & )$^{b} 5$ & 10 & 20 \\
\hline \multicolumn{4}{|l|}{ Step 2} \\
\hline $\mathrm{T}^{\mathrm{o}} \mathrm{C}$ & 100 & 50 & \\
\hline $\mathrm{Ta}(\min )^{\mathrm{a}}$ & 5 & 5 & \\
\hline Time $(\mathrm{min})$ & )$^{\mathrm{b}} 10$ & 10 & \\
\hline
\end{tabular}




\section{RESULTS AND DISCUSSION}

A method for the simultaneous determination of $\mathrm{Al}, \mathrm{As}, \mathrm{Cd}, \mathrm{Cr}, \mathrm{Cu}$, $\mathrm{Fe}, \mathrm{Hg}, \mathrm{Mn}, \mathrm{Ni}, \mathrm{Pb}, \mathrm{Sn}$, and $\mathrm{Zn}$ in bulgur samples collected from southeastern Anatolia in Turkey in 2012 using ICP-OES is presented. The determination of the multielement concentration by atomic spectrometry techniques requires digestion and conversion of the food samples into solution prior to measurement. For sample preparation, the MW digestion uses a diluted oxidant. The MW digestion of solid samples followed by ICPOES analysis is a powerful approach to the complete decomposition and accurate determination of metals in food samples. It shortens the analysis time and minimizes the problems associated with solid sample pretreatment such as sample contamination and analyte loss $(4,29)$. A diluted oxidant mixture $\left(\mathrm{HNO}_{3} /\right.$ $\left.\mathrm{H}_{2} \mathrm{O}_{2}, 2: 1\right)$ was used to achieve the complete decomposition of the organic matrix in a closed-vessel microwave oven (Table III). The ICP-OES analytical method offers low spectral interference problems from other methods, high selectivity, reliability, and simplicity. The proposed procedure obtained the best results in the shortest period of time, uses the smallest amount of reagents and samples, with minimum contamination, little residue and waste generation, maintains the integrity of the sample and the traceability of the results, and provides quality and confidence in the measurements. As can be seen in Table IV, the method was validated through the analysis of CRM NIST 1573a Tomato Leaves (National Institute of Standards and Technology, Gaithersburg, MD, USA) with good recoveries (5).

Optical emission spectrometry (OES) with a plasma excitation source uses quantitative measurement of the optical emission from excited atoms to determine the analyte concentration. The high-temperature atomization source supplies sufficient energy to help the atoms into high energy levels. The atoms decay back to lower levels and emit light. Since the transitions are between distinct atomic energy levels, the emission lines in the spectra are narrow. The spectra of the multi-element samples can be very complex, and spectral separation of nearby atomic transitions requires a high resolution spectrometer. Since all atoms in a

Table IV

Accuracy Assessment Through the Analysis of the Tomato Leaves NIST 1573a Certified Reference

\begin{tabular}{lccr}
\hline Elements & $\begin{array}{c}\text { Certified } \\
\left(\mathrm{mg} \mathrm{kg}^{-1}\right)\end{array}$ & $\begin{array}{c}\text { Confidence Interval } \\
\text { Measured } \\
\left(\mathrm{mg} \mathrm{kg}^{-1}\right)\end{array}$ & $\begin{array}{c}\text { Recovery } \\
(\%)\end{array}$ \\
\hline $\mathrm{Al}$ & $598 \pm 12$ & $599 \pm 4$ & 100.16 \\
$\mathrm{As}$ & $0.112 \pm 0.004$ & $0.110 \pm 0.007$ & 98.21 \\
$\mathrm{Cd}$ & $1.52 \pm 0.04$ & $1.55 \pm 0.01$ & 101.97 \\
$\mathrm{Cr}$ & $1.99 \pm 0.06$ & $2.03 \pm 0.05$ & 102.00 \\
$\mathrm{Cu}$ & $4.70 \pm 0.14$ & $4.67 \pm 0.08$ & 99.36 \\
$\mathrm{Fe}$ & $368 \pm 7$ & $365 \pm 2$ & 99.18 \\
$\mathrm{Hg}$ & $0.034 \pm 0.004$ & $0.035 \pm 0.002$ & 102.94 \\
$\mathrm{Mn}$ & $246 \pm 8$ & $245 \pm 6$ & 99.59 \\
$\mathrm{Ni}$ & $1.59 \pm 0.07$ & $1.56 \pm 0.03$ & 98.11 \\
$\mathrm{~Pb}$ & $0.075 \pm 0.025$ & $0.076 \pm 0.012$ & 101.33 \\
$\mathrm{Zn}$ & $30.9 \pm 0.7$ & $31.6 \pm 1.2$ & 102.26 \\
\hline
\end{tabular}

\section{Atomic Apectroscopy 1 Vol. 36(5), Sept./Oct. 2015}

sample are excited simultaneously, they can be detected simultaneously, which is the major advantage of OES compared to other atomic spectroscopic methods (32-37). It is a suitable technique for this type of analysis because it also offers rapid and precise determination with a wide dynamic range and low limits of detection. These properties appropriate it to vie successfully with the more traditional techniques of flame atomic emission spectrometry, atomic absorption spectrometry, instrumental neutron activation analysis, and X-ray fluorescence $(2,24,27)$.

A continuous surveillance system of contaminants in food is, therefore, crucial for consumer protection and the facilitation of international trade (5). Risk assessment is an evolving process and new information on contaminants, their implicated health effects, and their occurrence in food should be continuously studied and monitored $(4,5)$. Of the studied elements, As, $\mathrm{Hg}, \mathrm{Cd}, \mathrm{Pb}$, and $\mathrm{Sn}$ are most toxic to humans. The bio-accumulation of these toxic metals can cause a number of deleterious and diverse effects. They can affect the function of the blood, the circulatory, nervous, kidney, hormonal, and the immune systems. Cramps, nausea, vomiting, diarrhea, loss of memory, stomach pain, headache, sweating, complaints such as metallic taste in the mouth are classic symptoms $(2,33,34)$.

In contrast, metals such as $\mathrm{Cu}$, $\mathrm{Cr}, \mathrm{Fe}, \mathrm{Mn}, \mathrm{Ni}$, and $\mathrm{Zn}$ are essential for humans. $\mathrm{Cr}$ is beneficial to those with impaired glucose tolerance. A meta-analysis on the relationship between $\mathrm{Cr}$ and impaired glucose tolerance showed a positive effect. Chromium deficiencies result in decreased insulin sensitivity, glucose intolerance, and increased risk of diabetes $(2,35)$. Copper is associated with bone health, immune function and frequency of infections, cardiovascu- 
lar risk, and alterations in cholesterol metabolism. Copper is important in respiration for the synthesis of hemoglobin, the protein that transports oxygen in the blood stream. Copper deficiency simultaneously leads to decreased Fe levels in some tissues and Fe deficiency to anemia, whereas it results in $\mathrm{Fe}$ overload in other tissues such as the intestines and liver (36). Iron is necessary for the synthesis of collagen and is present in the brain as a co-factor in the synthesis of serotonin, dopamine, and noradrenalin neurotransmitters. Its principlal function is through its interaction with proteins and copper in the formation of hemoglobin. Iron is also required for the production of hemoglobin in blood and myoglobin in muscles. Magnesium is an essential trace metal found in all tissues and is required for the normal amino acid, lipid, protein, and carbohydrate metabolism. It plays an important role in bone and cartilage development and wound healing and is a trace mineral which is essential to all forms of life on earth. It is only needed in very small amounts in the human body, so little in fact, that Mn deficiency has rarely been documented in humans. For humans, Mn is both an essential trace element and, at higher doses, a toxic metal. Due to the ubiquitous occurrence of Mn in foodstuff, daily dietary Mn uptake in industrial countries is higher in comparsion to the estimated daily requirement. Therefore, Mn deficiency is extremely rare. In contrast, chronic Mn toxicity, affecting primarily the central nervous system, is more prevalent $(2,38)$. Nickel aids in Fe absorption, as well as the adrenaline and glucose metabolism, and improves bone strength. It is in a delicate dance with other trace nutrients and vitamins to keep the body's system running smoothly. Since the body needs $\mathrm{Ni}$ in a small amount, Ni deficiency is rare. Large doses of Ni-containing dust absorbed through the nose or mouth may lead to very serious conditions such as bronchitis and even lung cancer. Excess Ni induces $\mathrm{Zn}$ deficiency symptoms. They correspond to the symptoms of Ni allergy in humans. Nickel intake by humans can then induce Ni dermatitis in Ni-sensitive women and men (39). Zinc, an essential trace mineral critical in wound healing, is required for the metabolic activity of 300 of the body's enzymes and is considered essential for cell division and in the synthesis of DNA and protein (2).

On the other hand, metals such as $\mathrm{Pb}, \mathrm{Cd}, \mathrm{As}, \mathrm{Hg}, \mathrm{Cu}, \mathrm{Al}, \mathrm{Fe}$, and $\mathrm{Zn}$ are known to become potentially toxic when present at high concentrations. The mineral and trace element content in raw legumes and their bulgur samples is reduced by using pressure cooking and oven drying at $80^{\circ} \mathrm{C}$ to variable degrees. It was reported that the mineral losses were between $8.69-28.5 \%$ in both types of bulgur (17). The Food and Agriculture Organization/World Health Organization (FAO/WHO) Joint Expert Committee on Food Additives has defined the provisional tolerable weekly intake (PTWI) for a chemical with no intended function as an estimate of the amount of the chemical that can be ingested weekly over a lifetime without appreciable health risk $(40,41)$.

The concentrations of $\mathrm{Al}, \mathrm{As}, \mathrm{Cd}$, $\mathrm{Cr}, \mathrm{Cu}, \mathrm{Fe}, \mathrm{Hg}, \mathrm{Mn}, \mathrm{Ni}, \mathrm{Pb}, \mathrm{Sn}$. and $\mathrm{Zn}$ in 30 bulgur samples of the present study ranged from 0.68 to 0.94 $\mathrm{mg} \mathrm{kg}^{-1} \mathrm{Al}, 0.16$ to $0.21 \mathrm{mg} \mathrm{kg}^{-1} \mathrm{Cr}$, 3.35 to $4.25 \mathrm{mg} \mathrm{kg}^{-1} \mathrm{Cu}, 19.63$ to $33.88 \mathrm{mg} \mathrm{kg}^{-1} \mathrm{Fe}, 9.24$ to $17.96 \mathrm{mg}$ $\mathrm{kg}^{-1} \mathrm{Mn}, 0.14$ to $0.37 \mathrm{mg} \mathrm{kg}^{-1} \mathrm{Ni}$, 0.22 to $0.24 \mathrm{mg} \mathrm{kg}^{-1} \mathrm{~Pb}, 0.11$ to $0.23 \mathrm{mg} \mathrm{kg}^{-1} \mathrm{Sn}$, and 9.24 to 19.36 mg kg-1 $\mathrm{Zn}$. The elements As, Cd, and $\mathrm{Hg}$ were not detected (< LOD). The relative standard deviation of most elements was below $2 \%$. (see Tables II and IV). The low levels of toxic elements found in wheat bulgur samples may be due to the fact that their concentrations are low in soil and/or the environment and/or that the forms of these elements in the soil are not active and difficult to absorb by these plants (42-44). Due to the processing, all the investigated minerals in bulgur wheat samples were less than the corresponding wheat samples.

The results of this study show that the bulgur wheat samples used in this research were found not to be polluted with toxic metals since the concentrations of the minerals were all below the WHO permissible limits and the USP2232 Elemental Contaminants in Dietary Supplements publication $(40,41)$.

\section{CONCLUSION}

Bulgur wheat is a health food and produced in high amounts. Bulgur is a pre-cooked product from different cereals, especially wheat, by parboiling, drying, and grinding It is easily prepared and a semi or ready-to-eat food, inexpensive and economical, whole grain, high protein, low fat, has a long shelf life, resists mildew contamination and insect attacks, inactivates enzymes and micro-organisms due to cooking and drying, is savory, and very nutritional. The original wheat kernel nutrients are encapsulated during the processing, do not absorb radiation, are a good source for folic acid and excessive dietary fiber contents, decreases phytic acid content in contrast to increasing the bran content, and reduces intestinal cancer risk. Mineral nutrients are absolutely essential for good health. The results presented in this paper enlarge the knowledge of the elemental composition of bulgur and will be useful and of interest in the toxicological and nutritional fields.

The proposed ICP-OES technique developed and validated for bulgur wheat samples purchased in SE Anatolia, Diyarbakir, Turkey, in 2012, is simple, rapid, accurate, and precise for the simultaneous determination of 12 essential and 
nonessential /toxic elements (Al, As, $\mathrm{Cd}, \mathrm{Cr}, \mathrm{Cu}, \mathrm{Fe}, \mathrm{Hg}, \mathrm{Mn}, \mathrm{Ni}, \mathrm{Pb}$, $\mathrm{Sn}$, and $\mathrm{Zn}$ ). The method can also be considered useful for the routine determination of elements in other foods as well as for quality control purposes. The accuracy of the method was verified and compared well with the certified values. A study of the mean element composition of the bulgur samples showed that $\mathrm{Fe}\left(26.75 \mathrm{mg} \mathrm{kg}^{-1}\right)>$ $\mathrm{Zn}\left(14.30 \mathrm{mg} \mathrm{kg}^{-1}\right)>\mathrm{Mn}(13.60 \mathrm{mg}$ $\left.\mathrm{kg}^{-1}\right)$ and $\mathrm{Cu}\left(3.80 \mathrm{mg} \mathrm{kg}^{-1}\right)$ were the most abundant species. The elements found to be at lower concentrations followed the order of $\mathrm{Al}$ $\left(0.81 \mathrm{mg} \mathrm{kg}^{-1}\right)>\mathrm{Ni}\left(0.25 \mathrm{mg} \mathrm{kg}^{-1}\right)>$ $\mathrm{Pb}\left(0.23 \mathrm{mg} \mathrm{kg}^{-1}\right)>\mathrm{Cr}(0.19 \mathrm{mg} \mathrm{kg}$ $\left.{ }^{1}\right)>\mathrm{Sn}\left(0.17 \mathrm{mg} \mathrm{kg}^{-1}\right)$, while As, Cd, $\mathrm{Hg}$ were below the detection limits.

This study shows that the metal concentrations of bulgur wheat in Turkey were found to be below the WHO permissible limits and, therefore, is safe for public consumption.

$\overline{\text { Received February 9, } 2015 .}$

\section{REFERENCES}

1. K.O.Soetan, O. O.Aiyelaagbe, and C. O. Olaiya, Afr. J. Biotechnol. 9, 382 (2010).

2. U. C. Gupta and S. C. Gupta, Pedosphere 24, 13 (2014).

3. H. Koksel, M. J. Edney, and B. Ozkaya, J. Cereal Sci. 29, 185 (1999).

4. K. S. Celik, F. Aydin, M. Z. Duz, I. Aydin, S. Erdogan, O. Akba, and C. Hamamci, At. Spectrosc. 35, 200 (2014).

5. M. Z. Duz, K. S. Celik, I. Aydin, S. Erdogan, F. Aydin, and C. Hamamci, At. Spectrosc. 33, 78 (2012).

6. S. Demirel, M. Tuzen, S. Saracoglu, and M. Soylak, J. Hazard. Mater. 152, 1020 (2008).

7. P. R. Shewry, M. J. Hawkesford, V. Piironen, A.-M. Lampi, K. Gebruers, D. Boros, A. A. M.
Andersson, P. Åman, M. Rakszegi, Z. Bedo, and J. L. Ward, J. Agric. Food Chem. 61, 8295 (2013).

8. Y. Rharrabti, C. Royo, D. Villegas, N. Aparicio, and L.F. García del Moral, Field Crops Research 80, 123 (2003).

9. E. Triboi, A. Abad, A. Michelena, J. Lloveras, J.L. Ollier, and C. Daniel, Europ. J. Agr. 13, 47 (2000).

10. M. Bayram, M. D. Oner, and S. Eren, J. Food Eng. 64, 43 (2004).

11. S. Singh and N. Singh, Food Res. Int. 43, 2277 (2010).

12. M. Bayram and M. D. Oner, J. Food Eng. 74, 232 (2006).

13. M. Bayram and M. D. Oner, J. Food Eng. 79, 181 (2007).

14. S. C. Sofuoglu, H. Guzelkaya, O. Akgul, P. Kavcar, F. Kurucaovali, and A. Sofuoglu, Food Chem. Toxicol. 64, 184 (2014).

15. L. N. Kahyaoglu, S. Sahin, and G. Sumnu, J. Food Eng. 98, 159 (2010).

16. M. Bayram, Food Cont. 17, 331 (2006).

17. N. Bilgicli, J Food Process Pres. 33, 590 (2009).

18. M. Bayram, M. D. Oner, and A. Kaya, J. Food Eng. 61, 331 (2004).

19. M. Bayram, J. Food Eng. 71, 179 (2005)

20. E. Bas, Appl. Math. Modell. 38, 4926 (2014).

21. M. Reicks, S. Jonnalagadda, A. M. Albertson, and N. Joshi, Nutrition Research 34, 226 (2014).

22. C. Niamnuy, S. Devahastin, and S. Soponronnarit, J. Food Eng. 123, 148 (2014).

23. C. Armanino, R. De Acutis, and M.R. Festa, Anal. Chim. Acta 454, 315 (2002).

24. M. Merdivan, E.Yilmaz, C. Hamamci, and R.S. Aygun, Food Chem. 87, 163 (2004).

25. H. Zhao, B. Guo, Y. Wei, and B. Zhang, Food Chem. 138, 1902 (2013).

26. S. Branch, S. Burke, P. Evans, B. Fairman, C.S.J.W. Briche, J. Anal. At. Spectrosc. 18, 17 (2003).

27. I. Aydin, U. Yuksel, R. Guzel, B. Ziyadanogullari, and F. Aydin, At. Spectrosc. 31, 67 (2010).

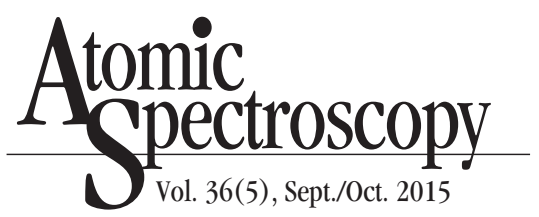

28. N. Xu, D. Gallimore, A. Martinez, and L. Townsend, J. Radioanal. Nucl. Chem. 297, 127 (2013).

29. F. C. Bressy, G. B. Brito, I. S. Barbosa, L.S.G. Teixeira, and M. G. A. Korn, Microchem. J. 109, 145 (2013).

30. O. Akba, A. Baysal, M. Merdivan, C. Hamamci, and B. Gumgum, Asian J. Chem. 17, 1518 (2005).

31. M.A. Morgano, L.C. Rabonato, R.F. Milani, L. Miyagusku, and S.C. Balian, Food Control, 22, 778 (2011).

32. O. Akba, E. Kilinc, I. Aydın, S. Erdogan, F. Aydin, M.Z. Duz, and C. Hamamci, At. Spectrosc. 34, 48 (2013).

33. M.G. Volpe, F. La Cara, F. Volpe, A. De Mattia, V. Serino, F. Petitto, C. Zavalloni, F. Limone, R. Pellecchia, P.P. De Prisco, and M. Di Stasio, Food Chem. 117, 553 (2009).

34. I. Aydin, F. Aydin, A. Saydut, E. G.Bakirdere, and C. Hamamci, Microchem. J. 96, 247 (2010).

35. F.Aydin, I. Aydin, O. Akba, S. Erdogan, B. Isik, and C. Hamamci, Pol. J. Environ. Stud. 21, 533 (2012).

36. F.Aydin, B. Gunduz, I. Aydin, O. Akba, A. Saydut, and C. Hamamci, At. Spectrosc. 34, 140 (2013).

37. I. Aydin, Microchem. J. 90, 82 (2008).

38. I. Aydin, B. Gunduz, F. Aydin, O.Akba, A. Saydut, and C. Hamamci, At. Spectrosc. 35, 241 (2014).

39. I. Aydin, F. Aydin, E. Kilinc, M.Z. Duz, C. Hamamci, Chem. Spec. and Bioavailab.. 25, 113 (2013).

40. Elemental Contaminants in Dietary Supplements $(<2232>)$, Pharmacopeial Forum 36(1) Jan/Feb 2010, Update PF 37(3), May/June 2012.

41. World Health Organization (WHO). WHO Food Additives Series, Geneva, Switzerland (2004).

42. I. Toufeili, C. Melki, S. Shadarevian, and R. K. Robinson, Food Qual Prefer. 10, 9 (1999).

43. G. Starr, W.L.P. Bredie, and Å.S. Hansen, J. Cereal Sci. 57, 295 (2013).

44. B. Olanca, D. S. Ozay, and H. Koksel, Eur. Food Res. Technol. 229, 813 (2009). 